\title{
Pertimbangan dan Sikap Milenial terhadap Minat Menggunakan $E$-Wallet: Pada Masa PSBB Pandemi Covid-19 di Kota Tangerang
}



Article History:

Received: September 4, 2020

Revised : October 23, 2020

Accepted: November 11, 2020

How to cite this article: Humairoh., Negara, A. K., \& Immawati, S. A. (2020). Pertimbangan dan Sikap Milenial terhadap Minat Menggunakan E-Wallet: Pada Masa PSBB Pandemi Covid-19 di Kota Tangerang. Organum: Jurnal Saintifik Manajemen dan Akuntansi, 3(2), 64-81. doi: https://doi.org/10.35138/organu m.v3i2.104

\section{Journal Homepage:} ejournal.winayamukti.ac.id/ind ex.php/Organum

\section{Copyright:}

(C) 2020. Published by Organum: Jurnal Saintifik Manajemen dan Akuntansi. Faculty of Economics and Business. Winaya Mukti University.
Abstract. The government's policy to prevent or reduce the spread of the Covid-19 virus is to enforce the Large-Scale Social Restrictions (LSSR) so that transactions that previously use paper money and cash turn into digital transactions. So far, e-wallets are considered as a transaction facility that makes it easier for users. This study aims to analyze the differentiation attributes that affect millennial considerations and attitudes towards usability to intention to use e-wallets during LSSR Covid-19 on millennials in Tangerang City. The research sample was 96 respondents using purposive sampling technique, namely millennials who use ewallets in making payments. The instrument used was a structured questionnaire with a Likert scale of 1-5, data processing using the Smart PLS program. This study's results, the intention to use ewallet of the millennial generation, were influenced by brand image, perceived ease of use, perceived usefulness through millennial consideration, and attitudes toward usability as intervening variables with $R^{2}$ adjusted 0.638. This study's results have implications for SMEs business actors to switch payment systems from cash payments to payments using e-wallets.

Keywords: Brand image; perceived ease of use; perceived usefulness; millennial consideration; attitudes toward usability; intention to use.

Abstrak. Kebijakan pemerintah dalam upaya memutuskan penyebaran virus Covid-19 adalah dengan memberlakukan Pembatasan Sosial Berskala Besar (PSBB), sehingga transaksi yang sebelumnya menggunakan uang kertas dan tunai beralih menjadi transaksi digital. E-wallet kini dianggap sebagai fasilitas transaksi yang memudahkan pengguna. Tujuan penelitian ini adalah untuk menganalisis atribut diferensiasi yang memengaruhi pertimbangan dan sikap milenial terhadap minat menggunakan $e$ wallet selama PSBB Covid-19 pada milenial di Kota Tangerang. Sampel penelitian sebanyak 96 responden diambil dengan menggunakan teknik purposive sampling, yaitu milenial yang menggunakan $e$-wallet dalam melakukan pembayaran. Instrumen yang digunakan adalah angket terstruktur dengan penilaian skala Likert (1-5), pengolahan data menggunakan program Smart PLS. Hasil penelitian ini, minat generasi milenial dalam menggunakan $e$-wallet dipengaruhi oleh citra merek, persepsi kemudahan penggunaan, persepsi kegunaan melalui pertimbangan dan sikap milenial sebagai variabel intervening dengan $\mathrm{R}^{2}$ adjusted 0.638 . Hasil penelitian ini berimplikasi pada pelaku usaha UKM untuk beralihnya sistem pembayaran dari pembayaran tunai menjadi pembayaran menggunakan $e$-wallet.

Kata Kunci: Citra merek; persepsi kemudahan; persepsi kegunaan; pertimbangan milenial; sikap penggunaan; minat menggunakan $e$-wallet. 


\section{Pendahuluan}

$\mathrm{P}$ emerintah Indonesia di dalam menghadapi bencana nasional pandemi Covid-19, menetapkan beberapa upaya yang telah dilakukan di antaranya dengan menerapkan Pembatasan Sosial Berskala Besar (PSBB) secara bertahap. Hal ini dimaksudkan untuk mengurangi terjadinya penyebaran penyakit, virus, morbiditas, dan akibat yang paling buruk adalah kematian yaitu dengan cara membatasi kontak fisik antara orang yang tidak terinfeksi dengan orang yang terinfeksi (Johnson, Sun, \& Freedman, 2020). Selain berujung kepada kematian, bencana Covid-19 ini juga telah mengakibatkan dampak negatif yang besar terhadap sosial ekonomi masyarakat (Nicola et al., 2020), keuangan (Goodell, 2020) dan rantai pasokan (Ivanov, 2020). Penerapan PSBB mengharuskan orang untuk berdiam diri di dalam rumah dan tidak melakukan kegiatan di luar rumah seperti biasanya, sehingga berakibat terdapat aktivitas rutinitas yang tidak lagi dilakukan secara fisik dalam memenuhi kebutuhan hidup, yaitu berbelanja di Usaha Kecil dan Menengah (UKM) (Fatoni, Susilawati, Yulianti, \& Iskandar, 2020). Hal ini menyebabkan perilaku konsumen berubah menjadi pembelanjaan online yang sebelumnya berbelanja secara fisik sehingga penjualan di bidang online semakin meningkat (Eloksari, 2020).

Kemajuan teknologi dan informasi menjadikan berbagai macam layanan dapat dilakukan secara digital. Mulai dari pemenuhan konsumsi makanan, minuman, transportasi, dan pakaian, semua mengalami digitalisasi, juga termasuk alat pembayaran belanja di UKM. Saat ini bentuk fisik uang mulai tersingkir sebagai alat pembayaran. Pada umumnya masyarakat sebelumnya menggunakan kartu ATM debit, kartu kredit, hingga e-money sebagai alat pembayaran. Kedudukan kartu pun mulai tergantikan dengan teknologi digital.
Penerapan PSBB menyebabkan dampak yang nyata bagi masyarakat untuk memenuhi berbagai kebutuhan hidup yang pada akhirnya masyarakat berbelanja menggunakan e-commerce. Pembatasan membayar dengan uang tunai dan kertas menyebabkan masyarakat beralih menggunakan $e$-wallet untuk mengurangi kontak fisik antara pembeli dengan penjual (Brown, 2020). E-wallet dapat membantu masyarakat dalam melakukan pembayaran. World Health Organization (WHO) menyatakan uang tunai dapat menjadi faktor penyebaran virus Covid-19. Walau belum diteliti kebenarannya, masyarakat beranggapan uang tunai yang kotor dapat menjadi media penyebaran virus sehingga membuat orang berasumsi untuk menggunakan pembayaran secara digital (Fatoni, Susilawati, Yulianti, \& Iskandar, 2020).

Dari tahun ke tahun di berbagai negara tingkat penerimaan mobile payment mengalami peningkatan (Flood, West, \& Wheadon, 2013). Di Indonesia dalam lima tahun terakhir semakin populer penggunaan layanan mobile payment, seiring dengan peningkatan pemakaian smartphone hingga mencapai 70\%. Ditambah lagi banyaknya pilihan aplikasi $e$-wallet tanpa menggunakan kartu di dalam pembayaran (Fatoni, Susilawati, Yulianti \& Iskandar, 2020). Dompet digital adalah segmen FinTech yang mengalami perkembangan signifikan. Hal ini dikarenakan bank sentral Indonesia lebih banyak mengimbau untuk melakukan transaksi secara digital (Bank Indonesia, 2020; IDN Financials, 2020). Bank Indonesia telah memberikan lisensi resmi terhadap $38 e$ wallet. Pasar dompet digital di Indonesia pada tahun 2018 mencapai Rp 21 triliun atau US\$ 1,5 miliar (Farras, 2019). Karena semakin maraknya perusahaan yang menyediakan $e$-wallet maka terjadilah persaingan yang ketat. Oleh karena itu, untuk mengantisipasi hal tersebut perusahan perlu mencari inovasi baru, 
dengan menciptakan nilai yang lebih unggul dibandingkan kompetitornya. Berdasarkan hasil survei Jakpat 2019, lima perusahaan tertinggi dompet digital adalah OVO, Dana, Go-Pay, LinkAja, dan Uangku. Analytics Data Advertising (ADA) (Jakpat, 2019) mencatat terjadi lonjakan hingga 300\% dalam penggunaan aplikasi belanja online ketika diterapkan social distancing. Masyarakat mendapatkan kemudahan dengan menggunakan $e$-wallet dalam bertransaksi secara online. Beberapa penelitian sebelumnya secara konsisten menemukan bahwa kegunaan yang dirasakan adalah prediktor kuat niat untuk menggunakan $e$ money (Aji, Berakon, \& Riza, 2020).

Studi empiris yang telah dilakukan pada remaja dalam niat penggunaan mobile banking di kota Chennai, Tamil Nadu yang dilakukan oleh (Shree P. N, Gurusamy, \& Balaji, 2019) di mana para peneliti menggunakan metode survei dan kuesioner terstruktur untuk mengumpulkan persepsi remaja terhadap niat penggunaan mobile banking. Hasil penelitian menunjukkan, dalam niat penggunaan mobile banking dalam kehidupan sehari-hari pada kaum muda dipengaruhi oleh beberapa faktor, antara lain faktor manfaat, kenyamanan, keamanan, kepercayaan, dan musyawarah. Studi empiris yang dilakukan oleh Revathy \& Balaji, (2020) di Negara India dihasilkan sebagian besar responden termasuk kategori milenial (umur 26-40 tahun, $\mathrm{F}=48,1 \%$ ) menyatakan bahwa alasan penggunaan $e$ wallet adalah keamanan dan keselamatan, kemudahan penggunaan, diskon penawaran, buat jadwal pembayaran, berbagai kegunaan, dan kecepatan pembayaran. Beralihnya milenial dalam bertransaksi menggunakan uang tunai ke pembayaran digital sangat menarik untuk diteliti, agar dapat diketahui apa yang menjadi pertimbangan dan sikap milenial dalam minat menggunakan layanan $e$ wallet pada masa PSBB Covid-19 di Kota Tangerang.

\section{Kajian Literatur}

\section{Minat Menggunakan $\boldsymbol{E}$-Wallet}

Dalam Karim, Haque, Arije, Hossain, \& Anis (2020), suatu tindakan yang ingin dicapai oleh individu adalah merupakan minat (Zhao, et al, 2010) dalam waktu periode tertentu (Ajzen, 1988), ini mengacu pada cara seseorang akan bertindak di masa depan (Fishbein, et al., 1975). Menurut TAM, perilaku pengguna dalam memakai teknologi ditentukan oleh minat, yang selanjutnya dapat menjadi perilaku aktual. Terdapat dua hal yang menentukan minat perilaku individu terhadap $e$-wallet, yaitu sikap individu terhadap norma subjektif dan penggunaan $e$-wallet (Camilleri, 2019 dalam Pertiwi, Suprapto, \& Pratama, 2020). Norma subjektif mengacu pada penggunaan $e$-wallet karena berasal dari pengaruh orang lain. Perilaku mengacu pada sikap kekurangan dan kelebihan saat menggunakan $e$-wallet. Minat perilaku adalah kecenderungan perilaku untuk terus berlanjut menerapkan teknologi (Liao et al., 2018 dalam Kustono et al., 2020)

\section{Sikap Penggunaan}

Sikap diartikan sebagai niat menggunakan $e$-wallet merupakan suatu bentuk keyakinan positif atau negatif yang dibentuk oleh sikap menuju objek dan perilaku (Hussein, 2017; Harsanto \& Jatnika, 2017 dalam Kustono, Yudistira, Nanggala, \& Mas, 2020). Individu percaya bahwa mereka dapat melakukan suatu perilaku yang akan menumbuhkan sikap penggunaan yang positif dan sebaliknya sikap penggunaan menggambarkan suatu pengalaman dan antisipasi masa lalu terhadap hambatan yang ada. Sikap positif yang dimiliki individu dalam perilaku mempunyai kecenderungan untuk memiliki niat dalam melaksanakan perilaku itu. Schiffman \& Kanuk (2007) dalam (Oentario, Harianto, \& Irawati, 2017) menyatakan, sikap konsumen adalah perasaan batin konsumen yang menunjukkan apakah 
konsumen suka atau tidak suka. Sikap konsumen akan memengaruhi seluruh kegiatan yang berhubungan dengan pemasaran (misalnya; merek atau layanan).

\section{Pertimbangan Milenial}

Work from home, study from home, \& stay at home adalah kebijakan yang diterapkan pemerintah untuk memutuskan penularan virus Covid-19 yang mempunyai dampak terhadap semua bidang kehidupan, sosial, ekonomi, teknologi, dan kesehatan. Penyebaran virus Covid-19 menyebar begitu cepat menjadikan perilaku kebiasaan milenial menjadi berubah dari bidang sosial, ekonomi, teknologi, dan kesehatan yang sehingga mempunyai suatu kebiasaan baru yang sebelumnya belum pernah dilakukan atau disebut dengan "The New Normal" (Fatoni, Susilawati, Yulianti, \& Iskandar, 2020).

Perubahan yang terjadi dalam bidang ekonomi adalah kebiasaan milenial yang sebelumnya berbelanja dengan bertemu langsung dengan penjual berubah menjadi secara online di mana dalam melakukan transaksi digunakan secara digital. E-Wallet sebagai alat pembayaran digital menyediakan cara dengan cepat, aman, dan nyaman bagi milenial sehingga milenial dapat bertransaksi di mana pun oleh siapapun dari toko di seluruh dunia. Sehingga $e$-wallet menjadi pertimbangan milenial menggantikan fungsi dompet yang menggunakan kartu.

Pertimbangan konsumen dalam memutuskan menggunakan teknologi merupakan proses pemikiran konsumen sebelum mengambil keputusan untuk menggunakan suatu produk. Di mana pertimbangan konsumen didukung oleh indikator berupa pencairan informasi, survei pada produk, pengaruh lingkungan, dan pengaruh perusahaan (William \& Slama, 1995).

\section{Citra Merek}

Citra merek telah menjadi konsep yang sangat penting karena implikasinya yang sangat besar bagi perusahaan. Menurut Bivainiene dalam (Alhaddad, 2015), citra merek adalah sekumpulan multifungsi fitur intangible dan tangible untuk mengidentifikasi produk. Campbell dalam (Alhaddad, 2015) mengartikan citra merek sebagai kombinasi antara keyakinan dan persepsi konsumen mengenai suatu merek. Aaker mengemukakan citra merek adalah kumpulan asosiasi yang merupakan segala informasi yang terkait mengenai produk, jasa dan perusahaan dari suatu merek (Alhaddad, 2015). Terdapat dua cara untuk mendapatkan informasi citra merek, yaitu secara langsung melalui pengalaman konsuman terdiri dari kepuasan emosional dan kepuasan fungsional. Pertama, merek harus dapat memahami baik kebutuhan konsumen maupun individual konsumen, serta dapat mengusung nilai-nilai yang diinginkan konsumen, yang akan memberikan arti atas hubungan tersebut selain memberikan performance seperti yang telah dijanjikan. Kedua, merek yang dibangun oleh perusahaan dari persepsi melalui berbagai bentuk komunikasi, antara lain logo, iklan, promosi, dan lainlain. Citra merek yang baik akan menimbulkan perasaan aman bagi konsumen (Biel, 1992). Citra merek yang diwujudkan dalam bentuk visual akan lebih mudah diingat oleh konsumen. Atribut ini didukung oleh indikator berupa inovasi, teknologi, dan citra (image) perusahaan.

Technology Acceptance Model (TAM), Persepsi Kemudahan, dan Persepsi Kegunaan

Technology Acceptance Model (TAM) adalah suatu bentuk model bagaimana suatu teknologi dapat diterima oleh pengguna (Bangkara \& Mimba, 2016). Persepsi kemudahan dan persepsi kegunaan merupakan faktor yang memengaruhi penerimaan penggunaan teknologi informasi. Persepsi kemudahan adalah keadaan di mana seseorang meyakini bahwa dengan menggunakan suatu sistem atau aplikasi, user dapat 
dengan mudah memahami tanpa memerlukan usaha apapun (free of effort) (Davis, 1989). Teknologi atau aplikasi tersebut akan dapat membantu meningkatkan performa dalam bekerja. User percaya bahwa aplikasi tersebut mudah dipahami, mudah dioperasikan, fleksibel, serta interaksi dan intensitas user dengan aplikasi menunjukkan sebagai karakteristik kemudahan penggunaan. Aplikasi yang mudah dioperasikan ditunjukkan dengan frekuensi penggunaan aplikasi yang tinggi dan lebih mudah dikenal oleh penggunanya. Indikator persepsi kemudahan adalah easy to use, less effort, clear, and understandable (Venkatesh \& Davis, 2000).
Persepsi kegunaan didefinisikan seberapa besar individu percaya bahwa suatu teknologi dapat membantu untuk meningkatkan kinerja (Davis, 1989). Persepsi kegunaan ditunjukkan oleh penilaian subjektif dari kegunaan yang ditawarkan untuk kemudahan mendapat jasa yang diinginkannya. Individu akan menggunakan teknologi atau aplikasi jika memberikan manfaat, sebaliknya individu tidak akan menggunakan jika teknologi atau aplikasi kurang memberikan manfaat. Indikator persepsi kegunaan sebagai berikut: beneficial, useful, productivity, dan productivity effectiveness (Venkatesh \& Davis, 2000).

\section{Bagan 1. Kerangka Konseptual Penelitian}

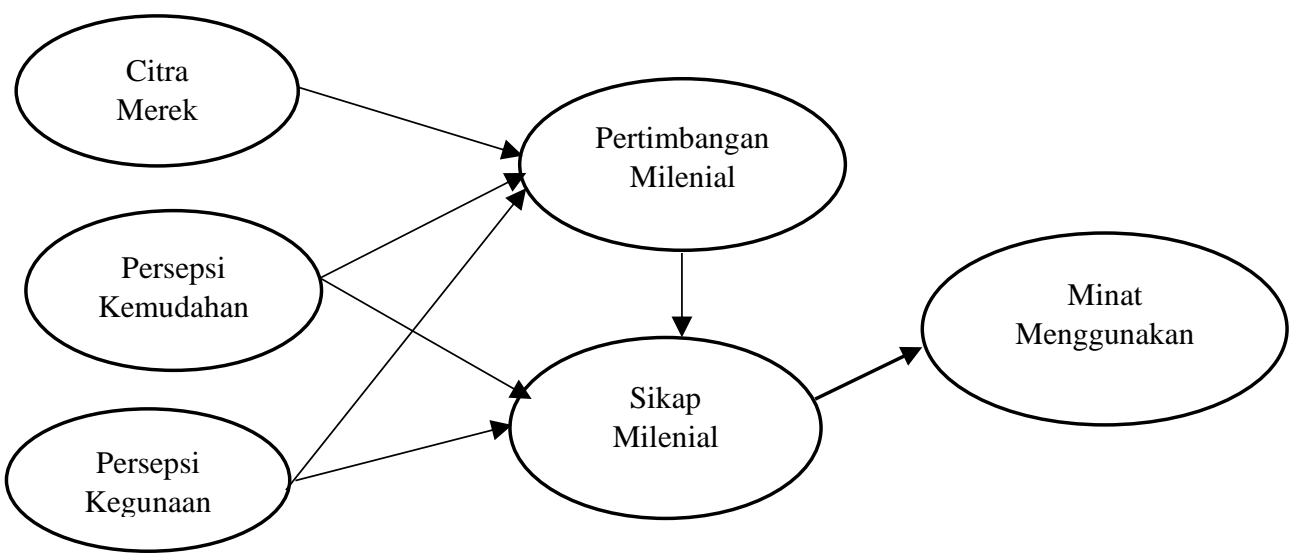

\section{Metode Penelitian}

Responden dalam penelitian ini adalah milenial yang lahir sekitar tahun 1994-1980 (kisaran umur 26-40 tahun). Pengambilan sampel menggunakan teknik purposive sampling, yaitu generasi milenial yang menggunakan $e$-wallet sebagai alat pembayaran dalam berbelanja yang bertempat tinggal di Kota Tangerang. Jumlah sampel sebanyak 96 responden dihasilkan berdasarkan rumus Lemeshow. Sampel diambil secara online pada masa PSBB Covid-19 yaitu pada bulan juni 2020 dengan menggunakan kuesioner terstruktur. Penilaian kuesioner digunakan skala Likert (1-5) yang menunjukkan skala sikap secara berurutan dari sikap sangat setuju, setuju, cukup setuju, tidak setuju, dan sangat tidak setuju. Data yang diperoleh diolah dengan menggunakan metode statistik secara deskriptif dan inferensial dengan bantuan software Smart PLS. Penyusunan hipotesis penelitian dibangun berdasarkan hasil studi literatur dan kerangka pemikiran penelitian, dengan variabel laten eksogen yang diduga menjadi faktor prediktor dari minat menggunakan $e$ wallet pada masa PSBB Covid-19. 


\section{Hasil dan Pembahasan}

\section{Profil Responden}

Responden dalam penelitian ini, adalah generasi milenial atau generasi $\mathrm{Y}$, generasi yang lahir sekitar tahun 1980 sampai tahun 1994 yang lahir setelah generasi X. Generasi milenial saat ini diperkirakan mempunyai rentang usia 26 tahun sampai 40 tahun. Disebutkan oleh Badan Pusat Statistik (BPS) bahwa pada tahun 2020 generasi milenial Indonesia akan mempunyai proporsi sebesar $34 \%$ atau sebanyak 83 juta dari keseluruhan penduduk Indonesia. Pengaruh generasi milenial dalam bisnis Indonesia sangat menonjol setidaknya untuk sepuluh tahun yang akan datang. Hal ini dikarenakan generasi milenial sebagian besar ada pada usia produktif (Santoso, 2017). Sebagian besar generasi milenial lahir dari latar belakang orang tua yang memiliki keuangan yang kuat dan secara kontekstual mereka berada di lingkungan yang kaya (Naim \& Lenka, 2018).

Tabel 1. Profil Responden

\begin{tabular}{|c|c|c|c|c|}
\hline No & Profil & Keterangan & $\begin{array}{c}\text { Jumlah } \\
\text { (Orang) }\end{array}$ & $\begin{array}{r}\text { Persentase } \\
(\%)\end{array}$ \\
\hline \multirow[t]{4}{*}{1} & Usia & 26 tahun - 29 tahun & 55 & 54,2 \\
\hline & & 30 tahun - 34 tahun & 22 & 22,9 \\
\hline & & 35 tahun - 40 tahun & 22 & 22,9 \\
\hline & & Jumlah & 96 & 100,0 \\
\hline \multirow[t]{3}{*}{2} & Gender & Laki-laki & 51 & 53,1 \\
\hline & & Perempuan & 45 & 46,9 \\
\hline & & Jumlah & 96 & 100,0 \\
\hline \multirow[t]{3}{*}{3} & Pendidikan & SMA & 13 & 13,5 \\
\hline & & $\mathrm{PT}$ & 83 & 86,5 \\
\hline & & Jumlah & 96 & 100,0 \\
\hline \multirow[t]{7}{*}{4} & Pekerjaan & Mahasiswa & 9 & 9,4 \\
\hline & & Karyawan Swasta & 58 & 60,4 \\
\hline & & PNS & 7 & 7,3 \\
\hline & & Pengajar & 14 & 14,6 \\
\hline & & Wirausaha & 6 & 6,3 \\
\hline & & Harian Lepas & 2 & 2,1 \\
\hline & & Jumlah & 96 & 100,0 \\
\hline \multirow[t]{8}{*}{5} & Jenis $e$-wallet & OVO & 27 & 28,1 \\
\hline & & DANA & 8 & 8,3 \\
\hline & & GOPAY & 12 & 12,5 \\
\hline & & DOKU & 1 & 1,0 \\
\hline & & LINK AJA & 1 & 1,0 \\
\hline & & ShopeePay & 1 & 1,0 \\
\hline & & $>1$ jenis $e$-wallet & 46 & 46,0 \\
\hline & & Jumlah & 96 & 100,0 \\
\hline \multirow[t]{3}{*}{6} & Apakah menggunakan & $\mathrm{Ya}$ & 19 & 20,0 \\
\hline & $e$-wallet karena ada & Tidak & 77 & 80,0 \\
\hline & pandemi & Jumlah & 96 & 100,0 \\
\hline \multirow[t]{4}{*}{7} & Lama menggunakan & $<1$ tahun & 23 & 24,0 \\
\hline & $e$-wallet & 1 tahun - 2 tahun & 27 & 28,1 \\
\hline & & $>2$ tahun & 46 & 47,9 \\
\hline & & Jumlah & 96 & 100,0 \\
\hline
\end{tabular}




\begin{tabular}{|c|c|c|c|c|}
\hline No & Profil & Keterangan & $\begin{array}{r}\text { Jumlah } \\
\text { (Orang) }\end{array}$ & $\begin{array}{r}\text { Persentase } \\
(\%)\end{array}$ \\
\hline \multirow[t]{4}{*}{8} & \multirow{4}{*}{$\begin{array}{l}\text { Frekuensi } \\
\text { menggunakan } \\
e \text {-wallet }\end{array}$} & 1 - 3 kali seminggu & 38 & 39,6 \\
\hline & & 4 - 7 kali seminggu & 55 & 57,3 \\
\hline & & $>7$ kali seminggu & 3 & 3,1 \\
\hline & & Jumlah & 96 & 100,0 \\
\hline \multirow[t]{3}{*}{9} & \multirow{3}{*}{$\begin{array}{l}\text { Apakah pada masa } \\
\text { pandemi sangat } \\
\text { membantu dalam } \\
\text { bertransaksi }\end{array}$} & $\mathrm{Ya}$ & 89 & 92,7 \\
\hline & & Tidak & 7 & 73 \\
\hline & & Jumlah & 96 & 100,0 \\
\hline \multirow[t]{7}{*}{10} & \multirow{7}{*}{$\begin{array}{l}\text { Transaksi penggunaan } \\
e \text {-wallet }\end{array}$} & Makanan dan Minuman & 19 & 19,9 \\
\hline & & $\begin{array}{l}\text { Tagihan (Pulsa, listrik, PAM, } \\
\text { CC, dll) }\end{array}$ & 11 & 11,5 \\
\hline & & Online Shop & 2 & 2,1 \\
\hline & & Entertainment (nonton, dll) & 4 & 4,2 \\
\hline & & Transportasi & 4 & 4,2 \\
\hline & & Semua Pembelanjaan & 56 & 58,3 \\
\hline & & Jumlah & 96 & 100,0 \\
\hline \multirow[t]{6}{*}{11} & \multirow[t]{6}{*}{$\begin{array}{l}\text { Alasan menggunakan } \\
e \text {-wallet }\end{array}$} & $\begin{array}{l}\text { Cash back/promo/discount yang } \\
\text { menarik/lebih hemat }\end{array}$ & 31 & 32,3 \\
\hline & & $\begin{array}{l}\text { Praktis/cepat tanpa membawa } \\
\text { uang/bisa digunakan di mana } \\
\text { saja/menghindari kontak } \\
\text { fisik/banyak pilihan merchant }\end{array}$ & 48 & 50,0 \\
\hline & & Keamanan & 10 & 10,4 \\
\hline & & Kenyamanan & 3 & 3,1 \\
\hline & & Mengikuti perkembangan zaman & 4 & 4,2 \\
\hline & & Jumlah & 96 & 100,0 \\
\hline
\end{tabular}

Sumber: Data primer yang diolah n=96 (2020)

Berdasarkan Tabel 1, profil generasi milenial yang menjadi responden dalam penelitian ini sebagian besar $(54,2 \%)$ mempunyai kelompok umur 25 tahun - < 30 tahun mempunyai jenis kelamin lakilaki $(53,1 \%)$ dengan tingkat pendidikan perguruan tinggi (86,5\%). Sebagian besar pekerjaan milenial adalah karyawan swasta $(60,4 \%)$, jenis $e$-wallet yang digunakan adalah OVO $(28,1 \%)$. Alasan digunakan $e$-wallet dominan milenial $(80,0 \%)$ menjawab bukan dikarenakan pandemi Covid-19, milenial telah menggunakan $e$-wallet lebih dari 2 tahun $(47,9 \%)$ lamanya sebelum terjadinya pandemi Covid-19. Namun, milenial mengakui bahwa pada masa pandemi frekuensi penggunaan $e$-wallet dalam bertransaksi menjadi bertambah hingga sebanyak 4-7 kali seminggu (57,3\%). Hal ini dikarenakan milenial mengikuti imbauan pemerintah untuk tidak keluar rumah (physical distancing) sehingga dalam memenuhi kebutuhan hidup transaksi yang digunakan frekuensinya lebih tinggi secara digital.

Pada masa PSBB Covid-19 milenial menyatakan $92,7 \%$ penggunaan $e$-wallet sangat membantu dalam bertransaksi. Milenial menggunakan e-wallet untuk transaksi pada hampir semua pembelanjaan $(58,3 \%)$ dengan alasan $e$ wallet praktis, lebih mudah, cepat tanpa harus membawa uang tunai, bisa digunakan di mana saja, dan menghindari kontak fisik, serta banyak pilihan merchant $(50,0 \%)$. Penggunaan aplikasi pembayaran dengan menggunakan $e$ wallet oleh milenial secara signifikan memperkuat bukti bahwa penggunaan 
sistem pembayaran dengan menggunakan $e$-wallet semakin meningkat. ADA menyebutkan terdapat peningkatan transaksi sebesar $300 \%$ oleh adaptive shopper dalam memenuhi kebutuhan sehari-hari (Fatoni, Susilawati, Yulianti, \& Iskandar, 2020).

\section{Evaluasi Model Pengukuran (Uji Validitas dan Reliabilitas)}

Tabel 2 memperlihatkan seluruh indikator penelitian ini adalah valid ditunjukkan dengan nilai Loading Factor $>0,70$; maka dinyatakan semua indikator valid. Evaluasi reliabilitas konstruk yaitu dengan melihat nilai Cronbach's Alpha dan nilai Composite Reliability, menunjukkan semua konstruk reliabel dengan nilai Cronbach's alpha > 0,50 dan Composite Reliability > 0,70; Berdasarkan hasil Average Variance Extracted memperlihatkan semua konstruk mempunyai AVE $>0,5$.

Tabel 2. Convergent Validity Variabel Penelitian

\begin{tabular}{lcccc}
\hline \multicolumn{1}{c}{ Konstruk } & $\begin{array}{c}\text { Loading } \\
\text { Factor }\end{array}$ & $\begin{array}{c}\text { Cronbach's } \\
\text { Alpha }\end{array}$ & $\begin{array}{c}\text { Composite } \\
\text { Reliability }\end{array}$ & AVE \\
\hline Citra merek & $0,714-0,874$ & 0,719 & 0,842 & 0,641 \\
Persepsi kemudahan & $0,799-0,878$ & 0,805 & 0,885 & 0,720 \\
Persepsi kegunaan & $0,882-0,953$ & 0,902 & 0,939 & 0,836 \\
Pertimbangan milenial & $0,715-0,873$ & 0,791 & 0,865 & 0,617 \\
Sikap penggunaan & $0,928-0,929$ & 0,840 & 0,926 & 0,862 \\
Minat menggunakan & $0,856-0,913$ & 0,875 & 0,923 & 0,800 \\
$e$-wallet & & 0 & \\
\hline
\end{tabular}

Sumber: Data primer yang diolah (2020)

\section{Evaluasi Goodness of Fit (GoF)}

Untuk mengevaluasi Goodness of Fit, dibutuhkan nilai akhir $\mathrm{R}^{2}$ pada tabel $R$-Square Adjusted. R-Square Adjusted konstruk pertimbangan milineal mempunyai nilai 0,577 menunjukkan konstruk pertimbangan milenial dapat dijelaskan oleh konstruk citra merek, persepsi kemudahan dan persepsi kegunaan sebesar 57,7\%; konstruk sikap milenial adalah 0,666 memberikan arti konstruk sikap milenial dapat dijelaskan oleh konstruk citra merek, persepsi kemudahan, persepsi kegunaan, dan pertimbangan milenial sebesar $66,6 \%$; dan konstruk minat menggunakan $e$-wallet adalah sebesar 0,638 artinya konstruk minat menggunakan $e$-wallet dapat dijelaskan oleh konstruk citra merek, persepsi kemudahan, persepsi kegunaan, pertimbangan, dan sikap milenial sebesar $63,8 \%$.

Tabel 3. R-Square Adjusted

\begin{tabular}{lc}
\hline \multicolumn{1}{c}{ Konstruk } & $\boldsymbol{R}$-Square Adjusted \\
\hline Pertimbangan milenial & 0,577 \\
Sikap penggunaan & 0,666 \\
Minat menggunakan $e$-wallet & 0,638 \\
\hline
\end{tabular}

Sumber: Data Primer yang diolah (2020)

Untuk menilai Goodness of Fit (GoF) menggunakan formula

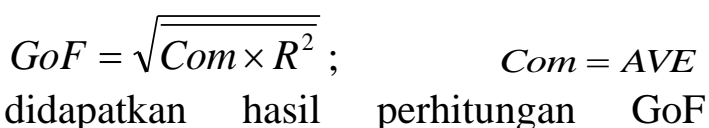


pertimbangan milenial sebesar 0,356, sikap milenial sebesar 0,574 dan minat menggunakan e-wallet sebesar 0,510. Dihasilkan nilai GoF antara 0 sd 1 dengan interpretasi nilai-nilai: 0,1 (GoF kecil), 0,25 (GoF moderat), dan 0,36 (GoF besar). Maka dapat diperoleh kesimpulan, seluruh model struktur adalah fit.

Tabel 4. Nilai Korelasi Antarkonstruk

\begin{tabular}{lccc}
\hline \multicolumn{1}{c}{ Konstruk } & & Konstruk & R \\
\hline Citra merek & & & 0,692 \\
Persepsi kemudahan & $<-->$ & Pertimbangan millenial & 0,701 \\
Persepsi kegunaan & $-->$ & Pertimbangan millenial & 0,662 \\
Persepsi kemudahan & Pertimbangan millenial & 0,632 \\
Persepsi kegunaan & $->$ & Sikap penggunaan & 0,680 \\
Pertimbangan milenial & $<->$ & Sikap penggunaan & 0,797 \\
Sikap penggunaan & $-->$ & Sikap penggunaan & 0,801 \\
\hline
\end{tabular}

Sumber: Data Primer yang diolah (2020)

\section{Evaluasi Model Struktural}

Berdasarkan hasil Latent Variable Correlations menunjukkan hubungan variabel antarkonstruk mempunyai hubungan yang kuat > 0,6.

\section{Gambar 1. PLS Algorithm Output}

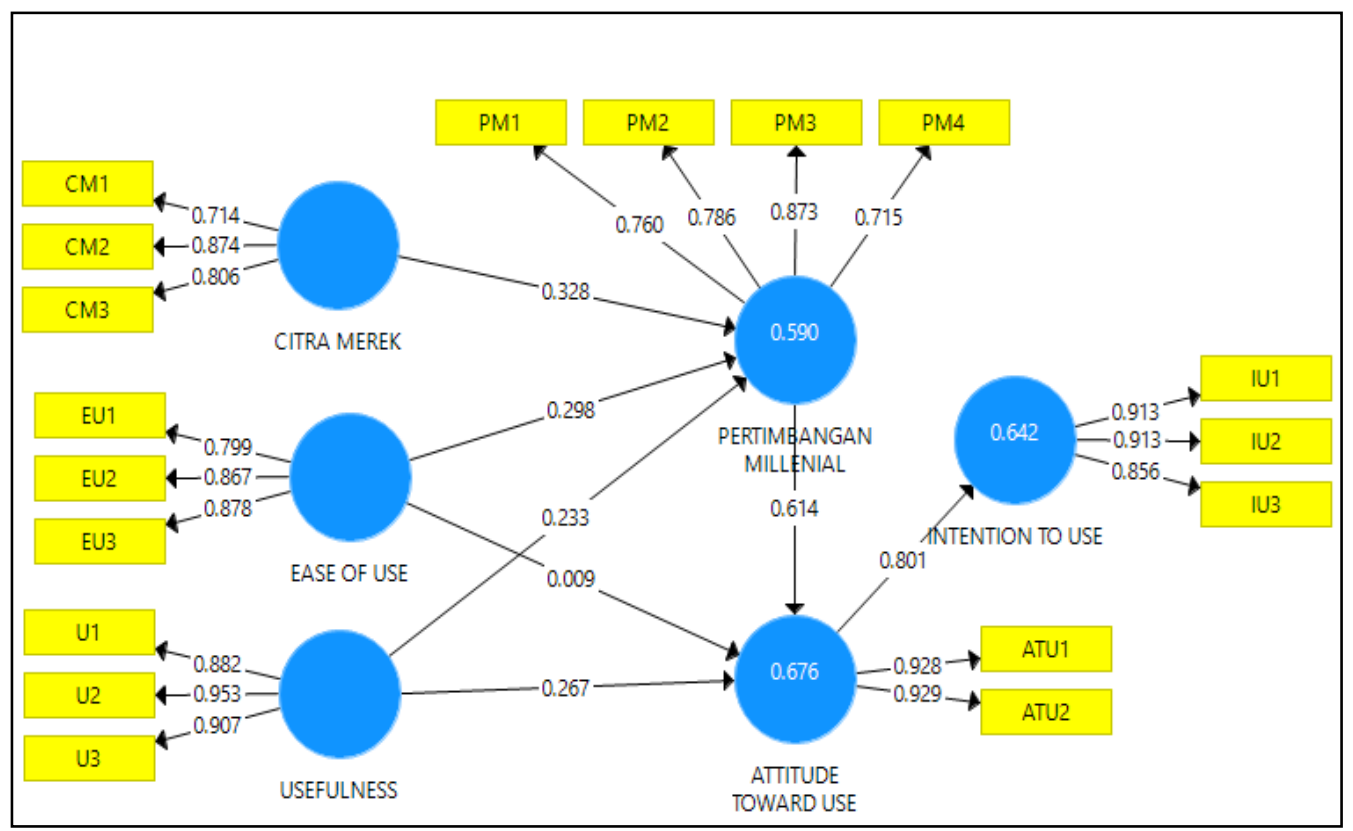

Sumber: Data Primer yang diolah (2020) 


\section{Pengujian Hipotesis}

Untuk menguji tingkat signifikan hipotesis penelitian yaitu dengan membandingkan $t$ hasil perhitungan dengan $\mathrm{t}$ tabel. Tingkat signifikan yang digunakan adalah 95\% (t tabel $=1,96)$. Dinyatakan signifikan jika $\mathrm{t}$ hitung $>\mathrm{t}$ tabel.

\section{Gambar 2. Nilai CR Hubungan Jalur}



Sumber: Data Primer yang diolah (2020)

Tabel 5. Hubungan Jalur

\begin{tabular}{|c|c|c|c|c|}
\hline Pengaruh Langsung & $\begin{array}{c}\text { Path } \\
\text { Coefficients }\end{array}$ & $\mathbf{C R}$ & $\begin{array}{c}\text { P- } \\
\text { Value }\end{array}$ & Keterangan \\
\hline Citra merek -> Pertimbangan milenial & 0,328 & 2,168 & 0,031 & Signifikan \\
\hline $\begin{array}{l}\text { Persepsi kemudahan -> Pertimbangan } \\
\text { milenial }\end{array}$ & 0,298 & 2,132 & 0,034 & Signifikan \\
\hline $\begin{array}{l}\text { Persepsi kegunaan -> Pertimbangan } \\
\text { milenial }\end{array}$ & 0,233 & 1,670 & 0,096 & $\begin{array}{l}\text { Tidak } \\
\text { Signifikan }\end{array}$ \\
\hline $\begin{array}{l}\text { Persepsi kemudahan -> Sikap } \\
\text { penggunaan }\end{array}$ & 0,009 & 0,056 & 0,955 & $\begin{array}{l}\text { Tidak } \\
\text { Signifikan }\end{array}$ \\
\hline Persepsi kegunaan -> Sikap penggunaan & 0,267 & 2,090 & 0,038 & Signifikan \\
\hline $\begin{array}{l}\text { Pertimbangan milenial -> Sikap } \\
\text { penggunaan }\end{array}$ & 0,614 & 5,945 & 0,000 & Signifikan \\
\hline $\begin{array}{l}\text { Sikap penggunaan }->\text { Minat } \\
\text { menggunakan } e \text {-wallet }\end{array}$ & 0,801 & 18,395 & 0,000 & Signifikan \\
\hline
\end{tabular}

Pengaruh Tidak Langsung

\begin{tabular}{lllll}
\hline Citra merek -> Pertimbangan milenial -> & 0,161 & 1,924 & 0,055 & Tidak
\end{tabular}

Minat menggunakan $e$-wallet

Signifikan

Persepsi kemudahan -> Pertimbangan

$0,154 \quad 1,981 \quad 0,049 \quad$ Signifikan

milenial -> Sikap penggunaan -> Minat

menggunakan $e$-wallet 
Persepsi kegunaan -> Pertimbangan

1,610

0,109

Tidak

milenial -> Sikap penggunaan -> Minat

Signifikan

menggunakan $e$-wallet

\section{Total Pengaruh}

Citra merek, Persepsi kemudahan dan

2,274

$7,923 \quad 0,000$

Signifikan

Persepsi kegunaan -> Pertimbangan

penggunaan -> Sikap milenial -> Minat

menggunakan $e$-wallet

Sumber: Data Primer yang diolah (2020)

H1: Citra merek berpengaruh signifikan terhadap pertimbangan milenial dengan path coefficient 0,328 dengan probability value 0,040 . Hal ini ditunjukkan dengan hasil pernyataan pengguna milenial merasa sangat setuju terhadap e-wallet dapat digunakan untuk bertransaksi secara online di berbagai merchant (42,7\%); pengguna milenial menyatakan sangat setuju $(70,8 \%)$ e-wallet dapat di top up saldo melalui gerai ritel, booth, internet banking, mobile banking, dan bank via ATM; dan pengguna milenial menyatakan setuju memilih perusahaan FinTech karena perusahaan tersebut terpercaya dalam mengelola keuangan (47,9\%). Citra merek adalah penentu yang memengaruhi persepsi subjektivitas pelanggan dan perilaku yang merupakan isyarat intrinsik ketika konsumen mengevaluasi suatu produk/ layanan sebelum membeli. Penelitian Bravo, Montaner, \& Pina, (2012) menghasilkan bahwa persepsi konsumen dipengaruhi oleh keakraban merek, komunikasi non-perusahaan, dan pada tingkat yang lebih rendah adalah iklan. Citra merek secara langsung menjadi anteseden dari sikap global terhadap perusahaan dan secara tidak langsung dari niat untuk menggunakan layanan bermerek. Citra perusahaan maupun keakraban dapat dikembangkan dengan menerapkan strategi komunikasi yang bijaksana yang menetralkan pengaruh informasi non-perusahaan yang negatif. Perusahaan yang mengembangkan citra perusahaan yang kuat harus lebih menarik bagi pelanggan. Citra merek memberikan solusi kepada konsumen dalam membentuk kebutuhan, keinginan membedakan merek, dan mengenali merek dari kompetitor lainnya (Anwar, Gulzar, Sohail, Bin, \& Akram, 2011).

H2: Persepsi kemudahan mempunyai pengaruh nyata terhadap pertimbangan milenial pada penggunaan $e$-wallet dengan path cofficient sebesar 0,298 dengan tingkat significance 0,046. Ini memberikan arti jika pesepsi kemudahan naik satu satuan maka pertimbangan milenial akan meningkat sebesar 0,298 satuan dengan asumsi variabel eksogen lain bernilai tetap. Persepsi kemudahan yang didapatkan oleh milenial adalah milenial percaya dengan teknologi, milenial akan bebas dari usaha. Hal-hal yang menjadi pertimbangan milenial dalam menggunakan $e$-wallet pada masa pandemik Covid-19 adalah pengguna milenial sangat setuju bahwa dengan $e$ wallet, milenial tidak perlu lagi membawa uang cash/tunai dan menghindari kontak fisik $(44,8 \%)$. WHO mengemukakan faktor penularan Covid-19 dapat disebabkan oleh uang dan publik secara psikologis beranggapan bahwa uang tunai yang kotor dapat menjadi media bagi penyebaran virus Covid-19 sehingga orang membuat asumsi untuk melakukan pembayaran secara digital; karena kemajuan teknologi milenial dapat melakukan pembayaran menggunakan $e$ wallet melalui smartphone $(61,5 \%)$; dan tampilan keseluruhan e-wallet ini user friendly dan mudah dipahami sehingga pengguna milenial terampil menggunakannya $(50,0 \%) . \quad$ E-Wallet memberikan solusi kemudahan dan 
kenyamanan untuk bertransaksi bisnis apapun terutama untuk mengurangi penggunaan uang tunai atau kertas, dan memungkinkan secara online milenial dapat bertransaksi menggunakan perangkat seluler.

H3: Persepsi kegunaan mempunyai pengaruh tidak nyata terhadap pertimbangan milenial dalam menggunakan e-wallet dengan path cofficient sebesar 0,223 dengan tingkat significance 0,096. Persepsi kegunaan dalam penggunaan $e$-wallet adalah sejauh mana milenial yakin dengan menggunakan suatu teknologi dalam bertransaksi dengan menggunakan $e$ wallet kinerja pekerjaannya akan meningkat. Persepsi kegunaan berpengaruh tidak nyata terhadap pertimbangan milenial, dikarenakan dengan diberlakukannya PSBB yang mengharuskan milenial tetap tinggal di dalam rumah (stay at home) pada masa pandemi Covid-19, maka segala pekerjaan dilakukan di rumah (work from home), pembelajaran dan perkuliahan dilakukan di rumah (study from home) sehingga tidak begitu tampak nyata terlihat membantu meningkatkan kinerja pekerjaan. Persepsi kegunaan dapat diukur dengan menggunakan indikator productivity, effectiveness, dan beneficial (Venkatesh \& Davis, 2000). Hasil wawancara dengan milenial pengguna $e$ wallet menyatakan sangat setuju terhadap pernyataan yang diajukan bahwa $e$-wallet ini mempunyai manfaat dalam membayar tagihan seperti listrik, telepon, PDAM, cicilan, dan lain-lain (62,5\%); e-wallet memudahkan dalam melakukan pembayaran $(60,4 \%)$; dan proses pembayaran dengan menggunakan $e$ wallet dapat lebih cepat/tidak membutuhkan waktu yang lama $(63,5 \%)$.

H4: Persepsi kemudahan mempunyai pengaruh tidak nyata terhadap sikap milenial dalam menggunakan $e$-wallet, dengan path coefficient 0,009 dan probability 0,955 . Persepsi kemudahan yaitu kepercayaan milenial dalam penggunaan suatu teknologi dalam hal ini $e$-wallet dapat dengan mudah digunakan dan dipahami berpengaruh tidak signifikan terhadap sikap milenial dalam menggunakan e-wallet. Hal ini dikarenakan milenial adalah generasi melek teknologi dan berada di era dimana teknologi sudah merupakan bagian dari perilaku milenial. Berdasarkan survei yang dilakukan oleh Kemendikbud berjudul Indonesia Millennial Report 2019 menunjukkan milenial Indonesia 94,4 persen telah terkoneksi dengan internet. Hasil survei memperlihatkan, milenial junior (usia 20-27 tahun) mengakses 4-6 jam sehari sebanyak 45 persen dan senior milenial (28-35 tahun) sebanyak 49 persen; junior milenial sebanyak 6,5 persen mengakses selama 7 10 jam sehari dan senior milenial 13,4 persen; dan junior milenial sebanyak 9,6 persen mengakses lebih dari 11 jam dan senior sebanyak 5,2 persen. Survei ini memberikan gambaran sebagian besar milenial Indonesia telah mengalami ketergantungan dan kecanduan terhadap internet. Diketahui sebanyak 79 persen milenial membuka ponsel 1 menit setelah bangun tidur (Harususilo, 2019). Hal ini menunjukkan milenial beranggapan tidak merasakan kesulitan dalam menerima teknologi dalam bertransaksi menggunakan smartphone. Namun, studi Mahwadha (2019) menghasilkan terdapat pengaruh persepsi kemudahan terhadap sikap menggunakan e-wallet Dana; Bangkara et al. (2016) dan Nasri \& Charfeddine (2012) yang menyatakan persepsi kemudahan mempunyai pengaruh nyata dan berhubungan positif terhadap sikap dalam menggunakan internet banking, serta Sianadewi, Widyarini, \& Wibowo (2017) menunjukkan pengaruh yang positif pada online shopping Notebook.com.

H5: Persepsi kegunaan mempunyai pengaruh nyata terhadap sikap milenial terhadap penggunaan $e$-wallet dengan path coefficient 0,267 p-value 0,038. Hal 
ini menunjukkan milenial percaya dengan memakai suatu teknologi akan menyebabkan kinerja pekerjaan meningkat (Davis, 1989) dan memberikan manfaat untuk orang yang menggunakannya. Pada masa pandemi Covid-19 dengan diberlakukannya physical distancing, milenial menggunakan transaksi dengan e-wallet dikarenakan $e$-wallet merupakan suatu transaksi pembayaran secara online dengan menggunakan internet, tanpa harus datang jauh-jauh untuk bertemu penjual. Penelitian ini memperkuat penelitian sebelumnya yang dilakukan oleh Mahwadha (2019) bahwa persepsi kegunaan memengaruhi sikap penggunaan $e$-wallet Dana; Sianadewi et al. (2017) pada online shopping. Penelitian Yasa, Ratnaningrum, \& Sukaatmadja (2014) dan Nasri \& Charfeddine (2012) terhadap penggunaan internet banking.

H6: Pertimbangan milenial berpengaruh nyata terhadap sikap penggunaan $e$-wallet dengan path coefficient 0,614 significance 0,000. Hal ini menunjukkan jika pertimbangan milenial naik sebesar 1 satuan maka sikap dalam menggunakan $e$ wallet akan meningkat sebesar 0,614 satuan. Pertimbangan milenial terdiri dari pencarian informasi, survei, dan pengaruh lingkungan. Pengguna milenial menyatakan sangat setuju pada pernyataan $e$-wallet mempunyai kehandalan dalam memberikan layanan pembayaran elektronik $(43,8 \%)$ dan $e$-wallet banyak memberikan promo cashback, saldo maupun point $(46,9 \%)$; dan menyatakan setuju pada pernyataan $e$-wallet menjaga uang dengan baik (38,5\%); e-wallet memberikan laporan transaksi secara langsung (real time) (44,8\%); dan temanteman, saudara saya sudah menggunakan $e$-wallet dalam bertransaksi $(39,6 \%)$. Dompet elekrtonik merupakan suatu program atau layanan website yang berguna bagi user untuk mengontrol dan menyimpan semua informasi belanja. $E$ wallet adalah suatu alat pembayaran yang dilakukan secara online dapat dilakukan dari toko mana pun oleh siapa pun dari seluruh dunia dengan menyediakan cara yang cepat, aman, dan nyaman. E-wallet menyediakan beberapa fitur keamanan yang memungkinkan pengguna dapat melacak pengiriman dan informasi tagihan, yang tidak dimiliki oleh dompet biasa.

H7: Sikap milenial mempunyai pengaruh nyata terhadap minat menggunakan $e$ wallet dengan path coefficient $0,801 p$ value 0,000 . Sikap terhadap minat menggunakan $e$-wallet adalah perasaan negatif atau positif jika harus melakukan perilaku penggunaan $e$-wallet. Sikap individu yang mendukung pemanfaatan teknologi sistem informasi akan secara otomatis mendorong penggunaan serta pemanfaatan teknologi sistem informasi (Davis, 1989). Beberapa studi empiris telah dilakukan sebelumnya oleh Mahwadha (2019) terdapat pengaruh attitude toward using terhadap perilaku penggunaan $e$-wallet pada konsumen usia muda; penelitian Purwanto, Hartini, \& Premananto (2019) terdapat pengaruh attitude toward using terhadap intention to use e-wallet Go-Pay; penelitian Lai (2012) $e$-wallet pada pembayaran biaya klinik di Taipei. Penelitian Nasri \& Charfeddine (2012) menunjukkan minat penggunaan internet banking dipengaruhi oleh sikap penggunaan internet banking. Menurut Mahwadha (2019) dan Purwanto et al. (2019) faktor yang paling signifikan mempunyai pengaruh terhadap minat diadopsinya $e$-wallet adalah sikap.

H8: Milenial dalam minat menggunakan $e$-wallet dipengaruhi oleh citra merek, persepsi kemudahan, persepsi kegunaan melalui pertimbangan, dan sikap penggunaan sebagai variabel intervening dengan path coefficient 2,274 dan significance 0,000 . Perilaku didorong jika sesorang mempunyai minat atau keinginan untuk melakukannya (Jogiyanto, 2007). Covid-19 yang begitu cepat menyebar luas mengakibatkan 
perubahan pada kebiasaan milenial, mulai dari bidang kesehatan, ekonomi bahkan teknologi, kebiasaan baru ini disebut dengan "The New Normal" yang menunjukkan suatu kebiasaan baru dianggap biasa yang sebelumnya merupakan sesuatu hal yang tidak normal. Pembayaran dalam transaksi yang sebelumnya dibayar secara tunai sekarang menjadi biasa untuk melakukan pembayaran dengan menggunakan $e$ wallet. Penelitian ini sejalan dengan penelitian Bangkara et al. (2016); Hosseini, Fatemifar, \& Rahimzadeh (2015); Shanmugam, Savarimuthu, \& Wen (2014) bahwa minat perilaku menggunakan mobile banking dipengaruhi oleh persepsi kegunaan dengan sikap penggunaan sebagai variabel intervening. Selanjutnya penelitian Kanchanatanee, Suwanno, \& Jarernvongrayab (2014) memberikan hasil sikap penggunaan memberikan efek tidak langsung dan langsung kepada persepsi kegunaan dengan minat menggunakan $e$ marketing. Dalam penggunaan teknologi pada pemakaian sistem pembayaran $e$ wallet dalam sektor usaha pada UKM, minat perilaku merupakan prediksi yang terbaik. Di berbagai negara, tidak terkecuali di Indonesia bagian yang penting dari perekonomian adalah usaha kecil dan menengah (Yusuf, 2012). Usaha kecil dan menengah mempunyai peran yang sangat besar dalam rangka peningkatan ekonomi kehidupan rakyat, ditunjukkan oleh kontribusinya terhadap penyerapan tenaga kerja, jumlah unit usaha, dan produksi nasional.

\section{Kesimpulan}

Pandemi Covid-19 telah memengaruhi dimensi kehidupan, baik di bidang sosial maupun ekonomi. Pemerintah berupaya untuk memutuskan penularan virus Covid-19, diantaranya adalah memberlakukan Pembatasan Sosial Berskala Besar (PSBB) yang membuat milenial untuk tetap tinggal/berdiam diri di dalam rumah, sehingga pemenuhan kebutuhan dilakukan secara online. Demikian pula, pembayaran yang biasanya menggunakan secara fisik uang tunai mulai berubah menggunakan dompet digital (e-wallet). Penelitian ini memberikan hasil citra merek berpengaruh signifikan terhadap pertimbangan milenial; persepsi kemudahan mempunyai pengaruh signifikan terhadap pertimbangan milenial; persepsi kegunaan berpengaruh tidak signifikan terhadap pertimbangan milenial; persepsi kemudahan berpengaruh tidak signifikan terhadap sikap penggunaan; persepsi kegunaan berpengaruh signifikan terhadap sikap penggunaan; pertimbangan milenial berpengaruh signifikan terhadap sikap penggunaan; sikap penggunaan berpengaruh signifikan terhadap minat menggunakan e-wallet; dan citra merek, persepsi kemudahan dan persepsi kegunaan berpengaruh positif dan signifikan terhadap minat menggunakan $e$-wallet melalui pertimbangan milenial dan sikap dalam menggunakan $e$-wallet sebagai variabel intervening. Nilai $\mathrm{R}^{2}$ adjusted pertimbangan milenial, sikap penggunaan dan minat menggunakan $e$ wallet masing-masing sebesar 0,577, 0,666 dan 0,638 .

Impilkasi manajemen yang dapat disarankan adalah 1) untuk mengurangi penyebaran virus Covid-19 dengan diterapkannya physical distancing, banyak milenial melakukan aktivitas di dalam rumah sehingga merubah perilaku milenial dalam berbelanja yang tadinya secara langsung menjadi berbelanja online maka bagi para pelaku usaha/UKM di Kota Tangerang dapat bekerja sama dengan perusahaan keuangan FinTech untuk menggunakan fasilitas layanan dompet digital/e-wallet dalam pembayaran; 2) untuk memudahkan dalam transaksi pembayaran hendaknya lembaga keuangan FinTech yang menyediakan $e$-wallet bekerjasama dengan bank pemerintah maupun swasta sehingga memudahkan milenial untuk 
melakukan top up; dan 3) dikarenakan penggunaan $e$-wallet menggunakan koneksi internet maka untuk perusahaan jasa telekomunikasi agar menyediakan jaringan internet yang stabil.

\section{Daftar Pustaka}

Aji, H. M., Berakon, I., \& Riza, A. F. (2020). The Effects of Subjective Norm and Knowledge about Riba on Intention to Use E-Money in Indonesia. Journal of Islamic Marketing. Advance online publication. doi: https://doi.org/10.1108/JIMA-10$\underline{2019-0203}$

Alhaddad, A. (2015). A Structural Model Of The Relationships Between Brand Image, Brand Trust, and Brand Loyalty. International Journal of Management Research \& Review, 5(3), 137-144. Diakses dari https://www.researchgate.net/public ation/277299980_A_STRUCTURA L_MODEL_OF_THE_RELATION SHIPS_BETWEEN_BRAND_IMA GE_BRAND_TRUST_AND_BRA ND_LOYALTY

Anwar, A., Gulzar, A., Sohail, F. B., \& Akram, S. N. (2011). Impact of Brand Image, Trust, and Affect on Consumer Brand Extension Attitude: The Mediating Role of Brand Loyalty. International Journal of Economics and Management Sciences, 1(5), 73-79. Diakses dari https://www.hilarispublisher.com/o pen-access/impact-of-brand-imagetrust-and-affect-on-consumerbrand-extension-attitude-themediating-role-of-brand-loyalty2162-6359-1-047.pdf

Badan Pusat Statistik. (2019). Statistik Indonesia 2019 (Indonesian Statistics). Jakarta: Badan Pusat Statistik. Diakses dari https://www.bps.go.id/publication/2 019/07/04/daac1ba18cae1e90706ee 58a/statistik-indonesia-2019.html

Bangkara, R. P., \& Mimba, N. P. S. H. (2016). Pengaruh Perceived Usefulness dan Perceived Ease of Use pada Minat Penggunaan Internet Banking dengan Attitude Toward Using sebagai Variabel Intervening. E-Jurnal Akuntansi, 16(3), 2408-2434. Diakses dari https://ojs.unud.ac.id/index.php /Akuntansi/article/view/21551

Bank Indonesia. (26 Maret 2020). Latest Economic Developments and Bank Indonesia Measures to Control COVID-19 (26th March 2020). Diakses dari https://www.bi.go.id/en/ruangmedia/infoterbaru/Pages/PerkembanganTerkini-Perekonomian-danLangkah-BI-dalam-HadapiCOVID-19-26032020.aspx

Biel, A. L. (1992). How Brand Image Drives Brand Equity. Journal of Advertising Research, 32(6), 6-12.

Bravo, R., Montaner, T., \& Pina, J. M. (2012). Corporate Brand Image of Financial Institutions: A Consumer Approach. Journal of Product and Brand Management, 21(4), 232245.

doi: https://doi.org/10.1108/1061042121 $\underline{1246649}$

Brown, D. (6 Maret 2020). Can cash carry coronavirus? World Health Organization says use digital payments when possible. USA Today. Diakses dari https://www.usatoday.com/story/mo ney/2020/03/06/coronavirus-covid19-concerns-over-usingcash/4973975002/

Davis, F. D. (1989). Perceived Usefulness, Perceived Ease of Use, And User Acceptance of Information Technology. MIS Quarterly: 
Management Information Systems, 13(3), 319-340. doi: https://doi.org/10.2307/249008

Eloksari, E. A. (20 Maret 2020). Food Deliveries, Online Game Purchases Up as People Stay at Home During COVID-19 Pandemic. The Jakarta Post. Diakses dari https://www.thejakartapost.com/ne ws/2020/03/20/food-deliveriesonline-game-purchases-up-aspeople-stay-at-home-during-covid19-pandemic.html

Farras, B. (20 Februari 2019). Pasar Dompet Digital RI Capai Rp $21 \mathrm{Tdi}$ 2018. CNBC Indonesia. Diakses dari

https://www.cnbcindonesia.com/fint ech/20190220154950-37-

56670/pasardompet-digital-ri-capairp-21-t-di-2018

Fatoni, S. N., Susilawati, C., Yulianti, L., \& Iskandar. (2020). Dampak Covid19 terhadap Perilaku Konsumen dalam Penggunaan E-Wallet di Indonesia. Digital Library, UIN Sunan Gunung Jati. Fakultas Syariah dan Hukum. Conference or Workshop Item. Diakses dari http://digilib.uinsgd.ac.id/id/eprint/3 $\underline{0953}$

Flood, D., West, T., \& Wheadon, D. (2013). Trends in Mobile Payments in Developing and Advanced Economies. RBA Bulletin, 71-80. Diakses dari https://www.rba.gov.au/publication s/bulletin/2013/mar/pdf/bu-0313$\underline{\text { 8.pdf }}$

Goodell, J. W. (2020). Covid-19 And Finance: Agendas for Future Research. Finance Research Letters, 35(April), 1544-6123 doi: https://doi.org/10.1016/j.frl.2020.10 $\underline{1512}$

Harususilo, Y. E. (30 Januari 2019). Survei: Bangun Tidur Generasi Milenial Langsung Pegang HP,
Kати?. Kompas.com. Diakses dari https://edukasi.kompas.com/read/20 19/01/30/12162041/survei-banguntidur-generasi-milenial-langsungpegang-hp-kamu?page =all

Hosseini, M. H., Fatemifar, A., \& Rahimzadeh, M. (2015). Effective Factors of The Adoption of Mobile Banking Services by Customers. Kuwait Chapter of Arabian Journal of Business and Management Review, 4(6), 1-13. doi: https://doi.org/10.12816/0018964

IDN Financials. (26 Maret 2020). BI Encourages Public to Use Non-Cash Transaction Method. IDN Financials. Diakses dari https://www.idnfinancials.com/new s/32945/encourages-public-noncash-transaction-method

Ivanov, D. (2020). Predicting The Impacts of Epidemic Outbreaks on Global Supply Chains: A Simulation-Based Analysis on The Coronavirus Outbreak (COVID-19/SARS-Cov2) Case. Transportation Research Part E: Logistics and Transportation Review, 136(March), 1366-5545. doi: https://doi.org/10.1016/j.tre.2020.10 $\underline{1922}$

Jakpat. (2019). Indonesia Digital Wallet Trend 2019 - JAKPAT Survey Report. Jakpat Blog. Diakses dari https://blog.jakpat.net/indonesiadigital-wallet-trend-2019-jakpatsurvey-report/

Jogiyanto. (2007). Sistem informasi keperilakuan. Yogyakarta: Andi.

Johnson, C. Y., Sun, L. H., \& Freedman, A. (11 Maret 2020). Social Distancing Could Buy U.S. Valuable Time Against Corona Virus. Washington Post. Diakses dari https://www.washingtonpost.com/h ealth/2020/03/10/social-distancingcoronavirus/ 
Kanchanatanee, K., Suwanno, N., \& Jarernvongrayab, A. (2014). Effects of Attitude toward Using, Perceived Usefulness, Perceived Ease of Use and Perceived Compatibility on Intention to Use E-Marketing. Journal of Management Research, 6(3), 1-13. doi: https://doi.org/10.5296/jmr.v6i3.55 $\underline{73}$

Karim, M. W., Haque, A., Ulfy, M. A., Hossain, M. A., \& Anis, M. Z. (2020). Factors Influencing the Use of E-wallet as a Payment Method among Malaysian Young Adults. Journal of International Business and Management, 3(2), 1-11. Diakses dari https://www.researchgate.net/public ation/340166261_Factors_Influenci ng the Use of E-

wallet_as_a_Payment_Method_amo ng_Malaysian_Young_Adults

Kustono, A. S., Nanggala, A. Y. A., \& Mas'ud, I. (2020). Determinants of the Use of E-Wallet for Transaction Payment among College Students. Journal of Economics, Business, \& Accountancy Ventura, 23(1), 85-95. doi:

\section{https://doi.org/10.14414/jebav.v23i} $\underline{1.2245}$

Lai, Y. H. (2012). The Study of Technology Acceptance for EWallets Application of Clinic Fees Payment. Scientific Research, 4(11), 1082-1087. doi: https://doi.org/10.4236/health.2012. $\underline{411165}$

Mahwadha, W. I. (2019). Behavioral Intention of Young Consumers Towards E-Wallet Adoption: an Empirical Study Among Indonesian Users. Russian Journal of Agricultural and Socio-Economic Sciences, 85(1), 79-93. doi: https://doi.org/10.18551/rjoas.2019$\underline{01.09}$
Naim, M. F., \& Lenka, U. (2018). Development and Retention of Generation Y Employees: A Conceptual Framework. Employee Relation, 40(2), 433-455. doi: https://doi.org/10.1108/ER-092016-0172

Nasri, W., \& Charfeddine, L. (2012). Factors Affecting The Adoption of Internet Banking in Tunisia: An Integration Theory of Acceptance Model and Theory of Planned Behavior. The Journal of High Technology Management Research, 23(1), 1-14. doi: https://doi.org/10.1016/j.hitech.201 $\underline{2.03 .001}$

Nicola, M., Alsafi, Z., Sohrabi, C., Kerwan, A., Al-Jabir, A., Iosifidis, C., Agha, M., \& Aghaf, R. (2020). The Socio-Economic Implications of The Coronavirus Pandemic (COVID-19): A Review. International Journal of Surgery, 78(April), 185-193. doi: https://doi.org/10.1016/j.ijsu.2020.0 $\underline{4.018}$

Oentario, Y., Harianto, A., \& Irawati, J. (2017). Pengaruh Usefulness, Ease of Use, Risk terhadap Intentionto Buy Onlinepatisserie melalui Consumer Attitude Berbasis Media Sosial di Surabaya. Jurnal Manajemen Pemasaran, 11(1), 2631.

doi: https://doi.org/10.9744/pemasaran.1 1.1.26-31

Pertiwi, D., Suprapto, W., \& Pratama, E. (2020). Perceived Usage of E-Wallet among the Y Generation in Surabaya Based on Technology Acceptance Model. Jurnal Teknik Industri, 22(1) 17-24. doi: https://doi.org/10.9744/jti.22.1.17$\underline{24}$

Purwanto, S., Hartini, S., \& Premananto, G. C. (2019). The Development and Testing of Technology Acceptance 
Models for Consumers towards the Intention to Use E-Wallet. Proceedings of The International Conference on Innovation in Research (ICIIR 2018), 88(Juli) 5561. doi: https://doi.org/10.2991/iciir18.2019 .11

Revathy, C., \& Balaji, P. (2020). Determinants of Behavioural Intention on E-Wallet Usage: An Empirical Examination in Amid of Covid-19 Lockdown Period. International Journal of Management, 11(6), 92-104. Diakses dari https://www.researchgate.net/public ation/342611112_DETERMINANT S_OF_BEHAVIOURAL_INTENTI ON_ON_EWALLET_USAGE_AN_EMPIRIC AL_EXAMINATION_IN_AMID OF COVID19_LOCKDOWN_PERIOD

Santoso, E. (2017). Millennial Finance. Jakarta: PT. Gramedia.

Shanmugam, A., Savarimuthu, M. T., \& Wen, T. C. (2014). Factors Affecting Malaysian Behavioral Intention to Use Mobile Banking with Mediating Effects of Attitude. Academic Research International, 5(2), 236253. Diakses dari http://paper.researchbib.com/view/p aper/17681

Shree P. N, S., Gurusamy, S., \& Balaji, P. (2019). Perception of Youth Towards Mobile Banking Usage Intention - an Empirical Study. Journal of Management, 6(2), 293301.

doi: https://doi.org/10.34218/jom.6.2.20 19.033

Sianadewi, J. H., Widyarini, L. A., \& Wibowo, W. (2017). Pengaruh Perceived Social Presence, Perceived Ease of Use, Perceived Usefulness, dan Attitude Towards
Online Shopping terhadap Niat Beli pada Jakarta Notebook.Com. Kajian Ilmiah Mahasiswa Manajemen, 6(2), 104-115. Diakses dari http://journal.wima.ac.id/index.php/ KAMMA/article/view/1778/1626

Venkatesh, V., \& Davis, F. D. (2000). Theoretical Extension of the Technology Acceptance Model: Four Longitudinal Field Studies. Management Science, 46(2), 186204. doi: https://doi.org/10.1287/mnsc.46.2.1 $\underline{86.11926}$

William, T. G., \& Slama, M.E. (1995). Market Mavens' Purchase Decision Evaluative Criteria: Implications for Brand and Store Promotion Efforts. Journal of Consumer Marketing, 12(3), 4-21. doi: https://doi.org/10.1108/0736376951 $\underline{0147218}$

Yasa, N. N. K., Ratnaningrum, L. P. R. A., \& Sukaatmadja, P. G. (2014). The Application of Technology Acceptance Model on Internet Banking Users in The City of Denpasar. Jurnal Manajemen dan Kewirausahaan (Journal of Management and Entrepreneurship), 16(2), 93-102. doi:

https://doi.org/10.9744/jmk.16.2.93 $\underline{-102}$

Yusuf. (2012). Pengaruh Inflasi dan Suku Bunga Serta Pemberian Kredit terhadap Perkembangan Aset UMKM di Indonesia. Academia.edu. Diakses dari https://www.academia.edu/9540947 /PENGARUH_INFLASI_DAN_SU KU_BUNGA_SERTA_PEMBERI AN_KREDIT_TERHADAP_PERK EMBANGAN_ASET_UMKM_DI INDONESIA 